\title{
Were Polish wild boars exposed to Schmallenberg virus?
}

\author{
Julia Kęsik-Maliszewska ${ }^{1}$, Artur Jabłoński ${ }^{2}$, Magdalena Larska ${ }^{1}$ \\ ${ }^{1}$ Department of Virology, ${ }^{2}$ Department of Swine Diseases, \\ National Veterinary Research Institute, 24-100 Pulawy, Poland \\ julia.kesik@piwet.pulawy.pl
}

Received: March 3, $2017 \quad$ Accepted: May 23, 2017

\begin{abstract}
Introduction: A novel to Europe Schmallenberg virus (SBV) causes clinical disease manifested by reproduction disorders in farm ruminants. In free-living ruminants, SBV antibodies as well as the virus were detected. Recent studies also revealed SBV antibodies in wild boars. The study investigates SBV antibodies occurring in wild boars in Poland at the peak of recent virus epidemics in the country. Material and Methods: Samples collected from 203 wild boars culled during the 2012/2013 and 2013/2014 hunting season were serologically tested using multi-species cELISA. Attempted neutralisation tests failed due to poor serum quality. RT-PCR was implemented in seropositive and doubtful animals. Results: Two samples collected from wild boar in the winter of 2013 gave a positive result in ELISA, while another two from the 2012/2013 hunting season were doubtful. No SBV RNA was detected in spleen and liver tissues. Conclusion: Low SBV seroprevalence in wild boars, despite high incidence of SBV infections occurring simultaneously in wild ruminants, suggests that boars are unlikely to be a significant reservoir of the virus in the sylvatic environment in Poland.
\end{abstract}

Keywords: wild boar, Schmallenberg virus, antibodies, Poland.

\section{Introduction}

The Schmallenberg virus (SBV), first detected in 2011, is a representative of Orthobunyavirus genus in Europe. The disease caused by SBV affects farm ruminants inducing usually unapparent or mild symptoms and sometimes transient productivity disorders, resulting in underestimation of the occurrence of clinical cases. However, in utero infections may result in miscarriages, stillbirths, or foetal malformations causing severe economic losses. SBV, similarly to bluetongue virus (BTV), is transmitted by female blood-sucking midges of Culicoides genus. The faster spread of SBV in Europe in relation to BTV-8 $(27,30)$ might, however, suggest involvement of more numerous and/or effective reservoirs. Judging by the high frequency of SBVspecific antibodies in a broad spectrum of species, the virus may infect a wide variety of different reservoirs $(19,24)$. Indirect and direct SBV presence demonstrated by SBV-specific antibodies and virus detection has been reported in exotic and wild ruminants in zoos around Europe, even in urban areas such as downtown Warsaw or Paris $(17,18)$. Not only ruminants seem to be susceptible to SBV infection. Virus-specific neutralising antibodies have been also confirmed in dogs in Sweden (31). Moreover, SBV has been involved in neurological disorders observed in Belgian shepherd puppies from France (28). Notwithstanding, in free-living carnivores and small mammals, such as rodents and shrews, detection of SBV antibodies failed (24). SBV antibodies were also reported in camelids (camels, alpacas, and llamas) and elephants $(8,23)$. SBV transmission into wild boar (Sus scrofa) under the evidence of SBV seropositivity was also observed previously $(6,24)$. However, the antibodies were absent in domestic pigs in the field nearby the area where an SBV epidemic first occurred in Belgium (26). Antibodies specific to Akabane and Aino viruses (members of Simbu serogroup together with SBV) were found in $37 \%$ and $0.4 \%$ of Korean swine, respectively (22) and even more frequent for Akabane virus $(75 \%)$ in Taiwan, causing clinical disease in pigs (13). Free-living Suidae in Africa can 
also act as Akabane virus silent hosts without clinical symptoms in the virus-host-vector circulating cycle (12). Considering the wild range of hosts of Simbu sero-group viruses and the fact that some Culicoides species can also feed on birds (1), it would be also interesting to test this potential reservoir of the SBV.

Since SBV viraemia and RNAemia lasts only few days after experimental infection, and viral RNA could be detected occasionally up to 44 days only in sheep mesenteric lymph nodes and spleen (32), effective virus detection in blood and tissues of field cases is usually impossible. Antibody detection remains the method of choice in epidemiological investigation since antibodies can persist up to two years, although seroconversion does not necessarily reflect a productive infection. Wild boar is a second after roe deer (Capreolus capreolus) most abundant wild ungulate in Europe. The population of Polish wild boar doubled between 1999 and 2009. In the last five years, it remained at a stable level (approx. 270 thousand animals; approx. one individual per $\mathrm{km}^{2}$ ) with a small decline in 2015/2016 season (4), perhaps due to the emergence of African swine fever (ASF) which increased mortality and caused the need of stamping out. Wild boar may also be involved in the epidemiology of many important vector borne diseases, such as West Nile fever and related flavivirus infections (11). Since its contact with human habitats becomes more and more frequent, the species susceptibility to infectious diseases may put domestic animals at risk as well.
The aim of the study was to assess the susceptibility of Polish wild boar to SBV during the first wave of Schmallenberg epizooty in the country, as well as to answer whether the species may serve as a reservoir of the virus in wildlife. To our knowledge, this is the first study concerning SBV infection in wild boar conducted in Poland.

\section{Material and Methods}

Sample collection. In total, 203 serum samples were collected from wild boars culled in compliance with the Polish hunting law. None of the sampled animals showed any clinical signs or any post-mortem gross pathomorphological lesions. Spleen and liver samples were collected. Blood was taken from the jugular vein or directly from the heart. No ethical/welfare authority approval was required as the samples were collected post-mortem during evisceration by the certified hunters. The samples were collected in the 2012/2013 $(\mathrm{n}=44)$ and 2013/2014 $(\mathrm{n}=159)$ hunting season and originated from 11 Polish provinces (Fig. 1). The forest districts where the wild boars were sampled corresponded with the areas with a high percentage of SBV-antibody positive cervids in the studied years. Sampled animals were between half to ten years of age and of both genders.

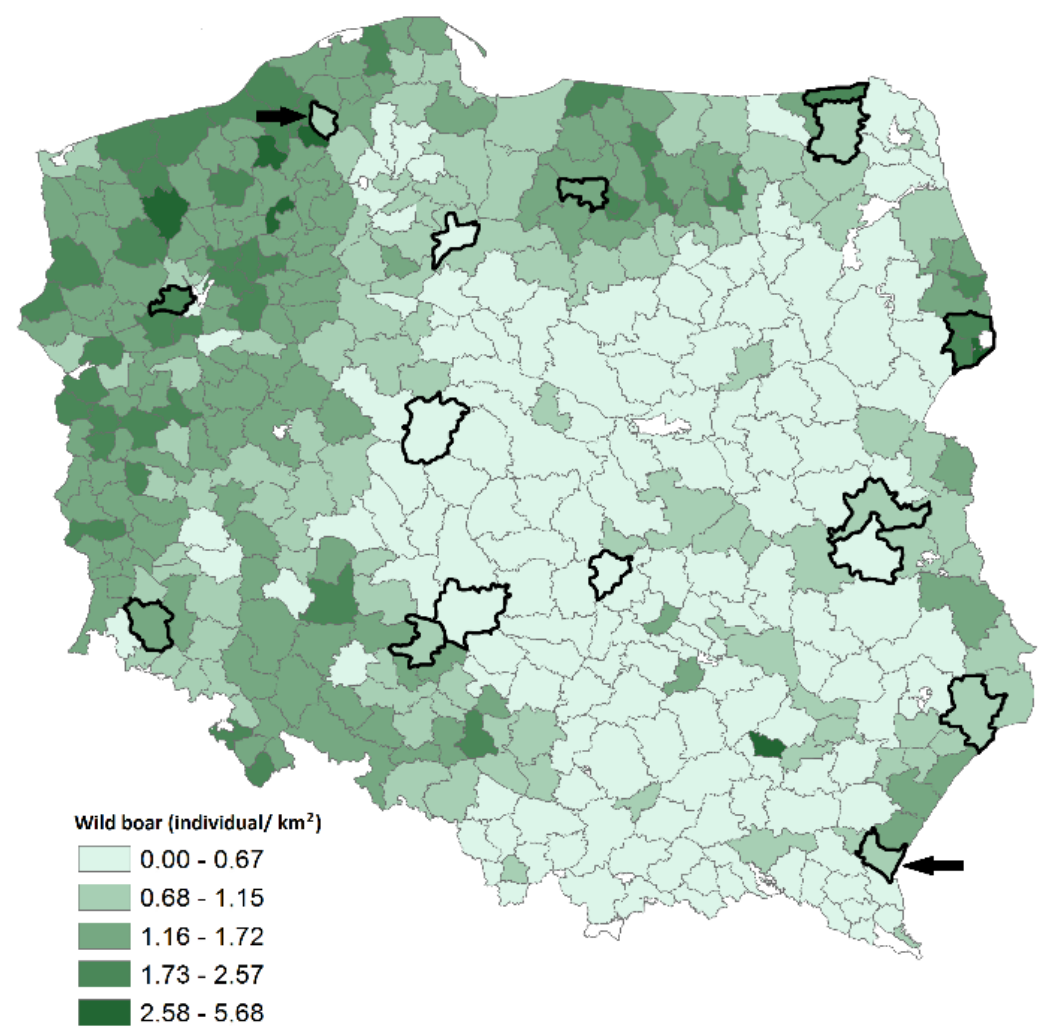

Fig. 1. Map presenting the Density of wild boar population in 2013 (in shades of green). Forest districts highlighted marked in black presents denote sampling sights; the ones with SBV antibodies in wild boars are pointed indicated by arrows 
Testing procedure. Commercially available multi-species cELISA (ID Screen Schmallenberg virus Competition Multi-species from ID.vet Innovative Diagnostics, France) was performed according to manufacturer's instruction to detect IgG antibodies to SBV nucleoprotein. The results of competition percentage $(\mathrm{S} / \mathrm{N} \%)$ calculated from the optical densities

$$
\left(\mathrm{S} / \mathrm{N} \%=\frac{\text { ODsample }}{\text { ODnegative control }} * 100\right.
$$

where OD values were optical densities measured at $450 \mathrm{~nm}$ on Multiscan EX photometer (Thermo Fischer Scientific, USA), were interpreted positive when below and equal to $40 \%$. The sensitivity and specificity given by the manufacturer amounted to $100 \%$; nevertheless, wild boar has not been specified in the test validation. The chosen test proved its usefulness in the studies on various free-living species, including wild boars (21, 24). When adequate volume of serum was assessable, samples were tested in duplicate and virus neutralisation test (VNT) was performed. Inactivated serum obtained from 37 wild boars was serially diluted in duplicate starting from $1 / 5$ dilution, incubated for $1 \mathrm{~h}$ at $37^{\circ} \mathrm{C}$ with $50 \mu \mathrm{L}$ of $100-300 \mathrm{TCID}_{50}$ of Polish SBV strain isolated from the cerebrum of a stillborn lamb, and passaged three times in baby hamster kidney 21 (BHK-21) cells. Next, $100 \mu \mathrm{L}$ of BHK-21 containing approx. $10^{4}$ cells $/ \mathrm{mL}$ was added to each well. Back titration of the virus, BHK-21 uninfected cells control, positive and negative serum control, and tested serum toxicity control were performed. The plates were incubated in $5 \% \mathrm{CO}_{2}$ at $37^{\circ} \mathrm{C}$ and the plates were checked for cytopathic effect after five days. The titre equal or greater than 5 was considered positive. A total of 20 good-quality, ELISA-negative sera and all seropositive and doubtful samples were tested by VNT.

Spleen and liver samples from seropositive or doubtful wild boar were homogenised in RLT buffer (Qiagen, Germany) using Lysing Matrix D Tubes (MP Biomedicals, France). Total RNA was extracted using RNeasy Mini Kit (Qiagen) in the automatic extraction station QIAcube (Qiagen). Primers and TaqMan probes for SBV S segment and $\beta$-actin, were used as internal control. RT-PCR was conducted with AgPath-ID OneStep RT-PCR (Ambion, Applied Biosystems, USA) in StepOne Real-Time PCR (Life Technologies, USA) after optimising the reaction temperature conditions to the following: $\mathrm{RT}-45^{\circ} \mathrm{C} / 10 \mathrm{~min}$; denaturation $-95^{\circ} \mathrm{C} / 10 \mathrm{~min} ; 42 \mathrm{PCR}$ cycles - denaturation $95^{\circ} \mathrm{C} / 15$ sec, annealing $56^{\circ} \mathrm{C} / 20 \mathrm{sec}$, elongation $72^{\circ} \mathrm{C} / 30 \mathrm{sec}$.

The map (Fig. 1) was prepared using ArcGIS 10.4.1 for Desktop software (ESRI, Inc.).

\section{Results}

From a total of 203 samples, only two $(0.99 \%)$ gave positive results in ELISA. They were collected from an adult wild boar sow from Subcarpathian Province $(\mathrm{S} / \mathrm{N} \%=31.7 \%)$ and a gilt from Pomeranian province $(\mathrm{S} / \mathrm{N} \%=36.1 \%)$ in the $2013 / 2014$ hunting season (seropositive made for $1.3 \%$ in this season). Additionally, another two doubtful results were detected in wild boar from warmian-Masurian province sampled in the $2012 / 2013$ hunting season $(4.5 \%$ in this season).

In the VNT, due to poor quality of most tested sera, toxic effect on BHK-21 cells in cell toxicity control wells occurred, making the test impossible to read. Only few ELISA-negative sera were confirmed negative in VNT. Back titration of the virus, cell control, and positive and negative serum control yielded the expected results. No SBV-S RNA was detected in RT-PCR in the spleen and liver samples from seropositive or doubtful wild boars, while the housekeeping gene was shown to amplify in all samples and gave $C_{t}$ values at a range of 24.0-28.8.

\section{Discussion}

Schmallenberg virus was shown to produce only weak and short-time seroconversion after experimental subcutaneous infection in pigs (26). No viraemia was observed during challenge, which suggests that pigs are probably not capable of efficient horizontal transmission by the vector. However, low infectious dose $\left(2 \times 10^{3} \mathrm{TCID}_{50}\right)$, sufficient to induce infection in sheep and cattle, may have not been sufficient to provoke virus replication and detectable viraemia in pigs. Also, no SBV antibodies were found in piglets in the field, suggesting rather limited role of pigs in SBV epidemiology (26). However, serological results for Akabane showed the highest seropositive proportion and antibody titres in sows, newborns, and finishers, and the lower in piglets after 6 weeks of age, showing that this group is not representative and can bias the results (13).

Recent studies by Mouchantat et al. (24) and Desmecht et al. (6) showed that the susceptibility or possible exposure of wild boars may be greater than of the domestic pigs. SBV seroprevalence in German and Belgian wild boars has reached $33 \%$ and $27 \%$ respectively, at the Western European peak of SBV epizooty in the 2011/2012 hunting season. Interestingly, the neutralising titres in some wild boar sera exceeded those measured in cervid sera. Additionally, the agreement between ELISA and VNT results proved the usefulness of ID Screen Schmallenberg virus Competition Multi-species (ID.vet) test in wild boar studies. In both studies, the frequency of SBV antibodies in wild boars decreased with the year of sampling and corresponded with seroprevalence observed in young stock and wild ruminants. In the 2013/2014 hunting season no SBV antibodies were detected in wild boars in Germany, which could result from low virus circulation in the environment and antibody clearance from the population. 
Despite the usage of commercial ELISA with confirmed applicability in wild boar (24), the observed percentage of seropositive wild boars tested in Poland was very low. One cannot exclude inappropriate storing conditions and repeated freezing and thawing of the samples as well as blood haemolysis prior to centrifugation, which could have led to antibody level decline and false negative results in ELISA (2). The poor quality of the samples was also confirmed in the VNT. On the other hand, cervid serum samples collected during the same hunting and stored under similar conditions gave positive results (21). Inability to detect SBV RNA by real-time PCR was not surprising, since the virus disappears from the bloodstream quickly after the exposure or may not be detected at all in the case of pigs. As mentioned before, SBV does not cause persistent infection or prolonged RNAaemia as in the case of bluetongue virus, which may be detected months after the infection in the presence of circulating antibodies. The viraemia usually ends in a week after the infection and before the seroconversion. The antibodies are first detectable by ELISA or VNT 14 or 21 days post infection. The presence of SBV has been observed in lymphoid tissues up to 44 days after the infection of sheep; however, since Suidae are expected to have a lower susceptibility to the virus, finding even traces of its genetic material in the tested spleens of wild boar would be highly improbable. One of the SBV seropositive wild boars was an about one-year-old female. This could suggest infection and seroconversion of the animal in 2013 midge activity season (from May to October). The piglet born in spring 2013 and culled in January 2014 must have acquired active immunity, due to the fact that maternal antiviral antibodies decay in wild boar piglets lasts up to six months $(9,10,25)$.

In the autumn of 2012, when SBV emerged in Poland, the overall seroprevalence in farm and freeliving ruminants reached 3.4\% (19). By 2013, SBV seroprevalence increased ten-fold in domestic ruminants (20), and the virus continued to spread in subsequent years (21). In free-living ruminants, the percentage $(27.7 \%)$ of SBV seropositive animals was comparable to livestock at the end of 2013 (21). Since wild boars share the same environment with wild ruminants and the exposure rate should correspond, the expected SBV seroprevalence in wild boar should be higher. Therefore, two components of the problem should be considered. First of all, wild boars may not be resistant but less susceptible to SBV. This confirms the lower seroprevalence found in German wild boars (24) in relation to SBV seroprevalence found in domestic ruminants in Western Europe reaching 100\% in 2011 and 2012. Secondly, wild boars may not be frequently exposed to SBV due to the selectivity of the vector. Entomological studies conducted in Białowieża Primeval Forest in proximity of wild boar revealed the abundance of Culicoides species, also confirmed as SBV, BTV, and AHSV vectors (15). However, no contact between Culicoides and European wild boar has ever been reported. The analysis of midge bloodmeals in the southeastern USA revealed the presence of wild boar blood in C. biguttatus and C. spinosus, commonly feeding on American whitetailed deer and considered as vectors of BTV and epizootic haemorrhagic disease virus (EHDV) (29). Culicoides distribution study has shown the presence of Pulicaris group midges at the pig farm (16). C. obsoletus group and C. pulicaris, both most prevalent in Poland, seem to preferably feed on cattle, therefore the SBV seroprevalence may not be as high in suids $(3,19)$. In the German study, almost $80 \%$ of midges were found to contain bovine blood, while $14 \%$ of insects fed on pigs if the host was present at the farm (3). Notwithstanding, since Akabane and Aino virus infections transmitted by culicoids occur in pigs and wild swine, this may serve as an indirect proof of the occurrence of the contact $(12,13,22)$. Moreover, there are reports on other insects biting wild boar, such as mosquitos (1). There are also some observations suggesting the occurrence of a human-infecting bunyavirus Tahyna transmitted by Aedes spp. mosquito in pigs $(5,14)$.

In Poland, as well as in other European countries (24), there were no reports on cases of abortions or stillbirths in wild boars. One must consider, however, difficulties in conducting such observations in the wildlife. It is possible that the lower SBV antibody percentage in wild boars in Poland, compared to German and Belgian studies, is the result of an overall lower impact of SBV on Polish ruminant herds leading to a lower number of infected vectors and lower host exposure (21). High percentage of seropositive wild boars in German study may have also resulted from significantly higher number of animals sampled in North Rhine-Westphalia, where SBV originally emerged and where the highest percentage of clinical cases and seropositivity, reaching up to $100 \%$ in livestock, were recorded. In relation to country territory, wild boar density in Germany is probably 1.6 times higher, assessing by the hunting bags from the $2013 / 2014$ season $(4,7)$. Higher population density in combination with the abundance of SBV in livestock and Culicoides vector could have resulted in higher SBV antibody occurrence in German wild boars.

To summarise, SBV antibodies were present in approx. $1 \%$ of Polish wild boars tested, which suggests that the importance of the species in SBV transmission in the country is rather low. Detection of an SBV seropositive one-year-old wild boar in 2013 suggests continuous virus circulation in wildlife in Poland.

Conflict of Interests Statement: The authors declare that there is no conflict of interests regarding the publication of this article.

Financial Disclosure Statement: The work was funded by the National Centre of Research and 
Development (NCBiR) project No PBS2/A8/24/2013, except the wild boar sampling which was financed from the NCBiR project NR12-0126-10.

\section{Animal Rights Statement: None required.}

Acknowledgements: The authors are grateful to Łukasz Bocian for preparing wild boar density map.

\section{References}

1. Alcaide M., Rico C., Ruiz S., Soriguer R., Muñoz J., Figuerola J.: Disentangling vector-borne transmission networks: a universal DNA barcoding method to identify vertebrate hosts from arthropod bloodmeals. PLoS One 2009, 4, e7092.

2. Boadella M., Gortázar C.: Effect of haemolysis and repeated freeze-thawing cycles on wild boar serum antibody testing by ELISA. BMC Res Notes 2011, 4, 498-509.

3. Bartsch S., Bauer B., Wiemann A., Clausen P.H., Steuber S.: Feeding patterns of biting midges of the Culicoides obsoletus and Culicoides pulicaris groups on selected farms in Brandenburg, Germany. Parasitol Res 2009, 105, 373-380.

4. Central Statistical Office of Poland - Forestry Statistical Yearbook 2013. http://stat.gov.pl/obszary-tematyczne/rolnictwolesnictwo/lesnictwo/lesnictwo-2016,1,12.html.

5. Chang C.C.: Bunyaviruses. In: Diseases of Swine, edited by J.J. Zimmerman,Wiley-Blackwell, 2012, pp. 490-492.

6. Desmecht D., Garigliany M.M., Beer M., Schirrmeier H., Paternostre J., Volpe R., Linden A.: Detection of antibodies against Schmallenberg virus in wild boars, Belgium, 2010-2012. UIGB congress, 2013, Bruxelles, Belgium.

7. Deutscher Jagdverband, Jagdstatistik. https://www.jagdverband. de/node/3304.

8. European Food Safety Authority: "Schmallenberg" virus: analysis of the epidemiological data. (May 2013) Supporting Publications 2013, p. 22. www.efsa.europa.eu/publications.

9. Fenati M., Armaroli E., Corrain R., Guberti V.: Indirect estimation of porcine parvovirus maternal immunity decay in free-living wild boar (Sus scrofa) piglets by capture-recapture data. Vet J 2009, 180, 262-264.

10. Grochowska M., Larska M., Lechowski L., Żmudziński J.F.: Abundance and activity periods of Culicoides obsoletus (Ceratopogonidae, Insecta), a vector for arboviruses occurring in Poland, in the years 2008-2014. Annual multidisciplinary conference in Florence, IJAS Conference Series, 2015, Florence, Italy.

11. Gutiérrez-Guzmán A.V., Vicente J., Sobrino R., Perez-Ramírez E., Llorente F., Höfle U.: Antibodies to West Nile virus and related flaviviruses in wild boar, red foxes and other mesomammals from Spain. Vet Microbiol 2012, 159, 291-729.

12. Hamblin C., Anderson E.C., Jago M., Mlengeya T., Hipji K.: Antibodies to some pathogenic agents in free-living wild species in Tanzania. Epidemiol Infect 1990, 105, 585-594.

13. Huang C.C., Huang T.S., Deng M.C., Jong M.H., Lin S.Y.: Natural infections of pigs with akabane virus. Vet Microbiol 2003, 94, 1-11.

14. Johnson N., Voller K., Phipps L.P., Mansfield K., Fooks A.R.: Rapid molecular detection methods for arboviruses of livestock of importance to northern Europe. J Biomed Biotechnol 2012, doi: 10.1155/2012/719402.

15. Kęsik-Maliszewska J., Krzysiak M.K., Grochowska M., Lechowski L., Larska M.: Entomological monitoring as a part of epizootic surveillance of Schmallenberg virus circulation in the Bialowieza National Park breeding reserves. International conference Wisent in the forests of Pszczyna- 150 year of breeding, 2015, Pszczyna, Poland.

16. Kirkeby C., Bødker R., Stockmarr A., Lind P., Heegaard P.M.: Quantifying dispersal of European Culicoides (Diptera:
Ceratopogonidae) vectors between farms using a novel markrelease-recapture technique. PLoS ONE 2013, 8, e61269.

17. Krzysiak M.K., Iwaniak W., Kęsik-Maliszewska J., Olech W., Larska M.: Serological study of exposure to selected arthropodborne pathogens in European bison (Bison bonasus) in Poland. Transbound Emerg Dis 2016, doi: 10.1111/tbed.12524.

18. Laloy E., Braud C., Bréard E., Kaandorp J., Bourgeois A., Kohl M., Meyer G., Sailleau C., Viarouge C., Zientara S., Chai N.: Schmallenberg virus in zoo ruminants, France and the Netherlands. Emerg Infect Dis 2016, 22, 2201-2203.

19. Larska M., Kęsik-Maliszewska J., Kuta A.: Spread of Schmallenberg virus infections in the ruminants in Poland between 2012 and 2013. Bull Vet Inst Pulawy 2014, 58, $169-176$.

20. Larska M., Kęsik-Maliszewska J., Żmudziński J.F.: Current Schmallenberg virus epidemiological situation in Poland serological and entomological surveillance. $10^{\text {th }}$ Annual Meeting EPIZONE, 2016, Madrid, Spain.

21. Larska M., Krzysiak M.K., Kęsik-Maliszewska J., Rola J.: Cross-sectional study of Schmallenberg virus seroprevalence in wild ruminants in Poland at the end of the vector season of 2013. BMC Vet Res 2014, 10, 967-973.

22. Lim S.I., Kweon C.H., Tark D.S., Kim S.H., Yang D.K.: Serosurvey on Aino, Akabane, Chuzan, bovine ephemeral fever and Japanese encephalitis virus of cattle and swine in Korea. J Vet Sci $2007,8,45-49$.

23. Molenaar F.M., La Rocca S.A., Khatri M., Lopez J., Steinbach F., Dastjerdi A.: Exposure of Asian elephants and other exotic ungulates to Schmallenberg virus. PLoS ONE 2015, 10, e0135532.

24. Mouchantat S., Wernike K., Lutz W., Hoffmann B., Ulrich R.G., Börner K., Wittstatt U., Beer M.: A broad spectrum screening of Schmallenberg virus antibodies in wildlife animals in Germany. Vet Res 2015, doi: 10.1186/s13567-015-0232-x.

25. Müller T., Teuffert J., Staubach C., Selhorst T., Depner K.R.: Long-term studies on maternal immunity for Aujeszky's disease and classical swine fever in wild boar piglets. J Vet Med B Infect Dis Vet Public Health 2005, 52, 432-436.

26. Poskin A., Van Campe W., Mostin L., Cay B., De Regge N.: Experimental Schmallenberg virus infection of pigs. Vet Microbiol 2014, 170, 398-402.

27. Rossi S., Viarouge C., Faure E., Gilot-Fromont E., Gache K., Gibert P., Verheyden H., Hars J., Klein F., Maillard D., Gauthier D., Game Y., Pozet F., Sailleau C., Garnier A., Zientara S., Bréard E.: Exposure of wildlife to the Schmallenberg virus in France (20112014): higher, faster, stronger (than bluetongue)! Transbound Emerg Dis 2015, doi: 10.1111/tbed.12371.

28. Sailleau C., Boogaerts C., Meyrueix A., Laloy E., Bréard E., Viarouge C., Desprat A., Vitour D., Doceul V., Boucher C., Zientara S., Nicolier A., Grandjean D.: Schmallenberg virus infection in dogs, France, 2012. Emerg Infect Dis 2013, 19, 1896-1898.

29. Swanson D.A., Turnbull M.W.: Molecular identification of bloodmeals from Culicoides Latreille (diptera: Ceratopogonidae) in the Southeastern U.S.A. Proc Entomol Soc Washington 2014, 116, 351-357.

30. Stokes J.E., Baylis M., Duncan J.S.: A freedom from disease study: Schmallenberg virus in the south of England in 2015. Vet Rec 2016, 179, 435-439.

31. Wensman J.J., Blomqvist G., Hjort M., Holst B.S.: Presence of antibodies to Schmallenberg virus in a dog in Sweden. J Clin Microbiol 2013, 51, 2802-2803.

32. Wernike K., Hoffmann B., Bréard E., Bøtner A., Ponsart C., Zientara S., Lohse L., Pozzi N., Viarouge C., Sarradin P., Leroux-Barc C., Riou M., Laloy E., Breithaupt A., Beer M.: Schmallenberg virus experimental infection of sheep. Vet Microbiol 2013, 166, 461-466. 